\title{
Food Demand in Brazil: An Application of Shonkwiler \& Yen Two-Step Estimation Method
}

\author{
- Alexandre Bragança Coelho* - Danilo Rolim Dias de Aguiar ** \\ - James S. Eales $\star \star \star ~$
}

\begin{abstract}
Resumo
O objetivo deste artigo é analisar a demanda de alimentos no Brasil por meio da estimação de um sistema de demanda com dezoito produtos usando dados da Pesquisa de Orçamentos Familiares realizada em 2002 e 2003 (POF 2002/2003). A forma funcional utilizada foi o Quadratic Almost Ideal Demand System (QUAIDS). A estimação utiliza o Procedimento de Shonkwiler e Yen para lidar com o problema do consumo zero. Os resultados mostraram que as probabilidades de aquisição dos produtos básicos foram negativamente relacionadas com a renda familiar mensal, enquanto carnes, leite e outros produtos mostraram uma relação positiva. As variáveis de educação, regionais e de localização do domicílio também foram importantes no primeiro estágio da estimação. Em relação às elasticidades-renda, nenhum bem foi considerado inferior e seis de dezoito foram considerados bens de luxo.
\end{abstract}

\section{Palavras-Chave}

Demanda de alimentos, Modelo QUAIDS, Procedimento de Shonkwiler e Yen

\begin{abstract}
The objective of the analysis is to estimate a demand system including eighteen food products using data from a Brazilian Household Budget Survey carried out in 2002 and 2003 (POF 2002/2003). The functional form used was Quadratic Almost Ideal Demand System (OUAIDS). Estimation employs the Shonkwiler and Yen method to account for zero consumption. Results showed that purchase probabilities of staples foods were negatively related to family monthly income, while meat, milk and other products showed a positive relation. Regional, educational and urbanization variables were also important in the first stage estimation. While some of the goods had negative income coefficients, none were inferior and six of eighteen were luxuries based on second stage estimates.
\end{abstract}

\section{Keywords}

Brazilian Food Demand, QUAIDS Model, Shonkwiler \& Yen method

\section{JEL Classification}

D12, C25, R22

\footnotetext{
* Universidade Federal de Viçosa (UFV). Endereço para contato: Campus da Universidade Federal de Viçosa, s/n. Departamento de Economia Rural - Viçosa - MG. CEP: 36571-000. E-mail: acoelho@ufv.br.

** Universidade Federal de São Carlos (UFSCar), Campus de Sorocaba. E-mail: danilo@ufscar.br.

$\star \star \star$ Purdue University (USA). E-mail: eales@purdue.edu.

(Recebido em janeiro de 2008. Aceito para publicação em maio de 2009).
} 


\section{Introduction}

Food demand in Brazil has undergone major changes in the last few decades caused by structural shifts such as urbanization, changes in demographic characteristics and increase in women's participation in the labor force. Therefore, it is necessary to identify families' new consumption patterns thoroughly in order to support both the design of appropriate government policies and the implementation of business strategies.

In order to devise proper public policies, understanding of food demand patterns is crucial (BATALHA et al., 2005). In Brazil, income redistribution and food security programs have been implemented aiming to reduce income inequality, hunger, and poverty. In order to be implemented correctly, these programs must take into consideration how changes in income would affect food consumption.

Other kinds of government policies depending on demand information are product support and inflation control programs. In the case of support programs, the government needs to know how the consumption of a product has changed through time to devise policies to prevent supply shortages. For instance, previous studies (see HOFFMANN, 1995) have shown a decrease in home consumption of rice and beans and an increase in consumption of some fruits, vegetables and beef. Such trends should be considered as the government designs its support programs. Regarding inflation control, the percentage of household income spent on food has decreased in recent decades, but is still the second most important in families' expenses with an average share of 21\% (Instituto Brasileiro de Geografia e Estatística (IBGE, 2004b). Furthermore, food purchases are still the most important expense for low income families, mainly in Brazil's north and northeast areas. According to the 2002/2003 Brazilian Household Budget Survey (Pesquisa de Orçamentos Familiares (POF) 2002/2003), low income Brazilian families spend 33\% of their income on food. These households suffer the most when food prices increase, so policymakers must have good estimates of price elasticities as inflation control programs are designed. Finally, in terms of business strategies, information on consumption patterns is crucial to investment planning and to design marketing and product development programs.

In sum, demand function parameters provide useful information to the government, farmers and the private sector. Despite some previous studies of food demand in Brazil, ${ }^{1}$ this paper main contribution is to deal with the zero expenditure problem

1 See, for example, Bacchi (1989), Furtuoso (1981), Thomas et al (1991) for early studies and Aguero and Gould (2003), Menezes, Silveira e Azzoni (2005), Silveira et al. (2007a) and Silveira et al. (2007b) for more recent and comprehensive studies. 
usually present whenever large household consumption data are used and which is commonly overlooked in empirical applications. Therefore, the objective of the current effort is to fill this gap. This will be accomplished through the estimation of a food demand system comprised of 18 Brazilian food products. Besides price and income effects, the system will account for regional differences among food demand patterns, as well as differences between urban and rural areas and other household demographics.

\section{Data}

The data used in this analysis were obtained from the 2002/2003 Brazilian Household Budget Survey microdata ${ }^{2}$ (POF 2002/2003) carried out by the Brazilian Institute of Geography and Statistics (IBGE). This survey contains one week detailed diary of food purchases for at-home consumption by Brazilian households. The 2002/2003 survey is different from previous surveys for two main reasons: First, it covered the entire Brazilian territory, including rural areas, whereas previous surveys examined only urban consumption. Second, for the first time nonmonetary purchases ${ }^{3}$ were considered, which are very important in rural areas.

Eighteen food products were selected for study from POF's wide range of products according to their importance in consumers' food budget and the substitutability among them. The selected food products are: sugar, rice, bananas, potatoes, prime cut beef, low quality beef, manioc flour, beans, chicken, powdered milk, fluid milk, pasta, butter, margarine, French rolls, pork, cheese and tomatoes. ${ }^{4}$ Prices were obtained using unit values calculated from the microdata. Missing prices were replaced by average state prices. ${ }^{5}$ The sample size used in the estimation is 43,922 households.

\section{Methodology}

The use of Household Budget Survey microdata allows a specification of demand equations that capture heterogeneity among consumers. In consumer demand modeling, detailed demographic information allows treatment of exogenous preferences which is not possible with aggregate time series (YEN; KAN; SU, 2002). This usually represents a better description of different groups demand patterns and a

2 See IBGE (op. cit, 2004b).

3 According to IBGE (2004a), non-monetary purchases comprise everything that is produced, fished, hunted, collected or received in goods utilized or consumed during the survey and, at least in the last transaction, have not gone through a market.

4 See Appendix A3 for statistics on average expenditures.

5 See Appendix A4 for state price statistics. 
great adherence of models to reality (BLUNDELL; PASHARDES; WEBER, 1993; MANCHESTER, 1977). However, when microdata are used, the problem of zero expenditure often appears, that is, people often appear in these surveys consuming zero of different products. The causes are twofold: the infrequency of purchases, caused by the relatively short period of data collection and a corner solution to the consumer maximization problem. This represents a major estimation problem, since there is a censored dependent variable. This problem is particularly complicated in multivariate models such as demand systems (YEN; KAN; SU, op. cit.).

In this case, ordinary least squares estimates (OLS) are known to be biased and inconsistent (GREENE, 2000). In individual demands, maximum likelihood (ML) estimation of Tobit models may be performed. However, as far as demand systems are concerned, direct ML estimation of these models remains difficult when censoring occurs in multiple equations because of the need of evaluating multiple integrals in the likelihood functions (SHONKWILER; YEN, 1999). Besides, one stage models as Tobit assume that there is simultaneity between the purchase decision and the quantity decision. Haines, Guilkey, and Popkin (1988) argue that the food consumption decision should be modeled as a two-stage problem: not only these decision stages are different, but the variables concerning each stage may differ as well.

These issues stimulated the use of two-step estimation procedures with limited dependent variables to model food system demand estimation (HEIEN; WESSELS, 1990; SHONKWILER; YEN, op. cit.). These procedures allowed dealing with the zero consumption problem, were simpler than the direct ML estimation (LEE; PIT, 1986) and did not presented aggregation problems, since microdata could be readily used. As the Heien and Wessels procedure presented inconsistencies and performed poorly in Monte Carlo simulations, ${ }^{6}$ Shonkwiler and Yen (op. cit.) twostep estimation will be used in this paper.

Suppose initially that we wish to model the demand of $M$ food products and there are $\mathrm{N}$ households in the dataset. Shonkwiler and Yen approach this problem as a two-step estimation:

\section{First step}

$$
\begin{aligned}
& d_{i n}^{*}=Z_{i n}{ }^{\prime} \alpha_{i}+v_{i n} \\
& d_{i n}=\quad \begin{array}{l}
1 \text { if } d_{i n}^{*}>0 \\
0 \text { if } d_{\text {in }}^{*} \leq 0
\end{array} \text { for all } i=1, \ldots, M \& n=1, \ldots, N
\end{aligned}
$$

6 See Shonkwiler and Yen (op. cit.) for details. 


\section{Second step}

$$
\begin{aligned}
& y_{i n}^{*}=f\left(X_{i n}, \beta_{i}\right)+e_{i n} \\
& y_{\dot{i n}}=d_{\dot{n}} y_{\dot{i}}^{*} \text { for all } i=1, \ldots, M \& n=1, \ldots, N
\end{aligned}
$$

where

$d_{i n}^{*}=$ Unobserved variable representing the utility difference when the consumer buys or does not buy the ith food product;

$d_{i n}=$ Observed dichotomous variable representing whether the consumer buys $\left(d_{i n}=1\right)$ or does not buy $\left(d_{i n}=0\right)$ the ith food product;

$Z_{\text {in }}=$ Vector of exogenous variables which affects the purchase decision;

$\alpha_{i}=$ Parameter vector in the purchase decision equation;

$y_{\text {in }}=$ Observed dependent variable representing the consumed quantity of the ith food product;

$f\left(X_{i n}, \beta_{i}\right)=$ Functional form of the demand function;

$X_{i n}=$ Vector of exogenous variables which impact the quantity decision;

$\beta_{i}=$ Parameter vector in the quantity decision equation;

$v_{i n} \& e_{i n}=$ random errors.

Shonkwiler and Yen (op. cit.) argue that this system can be estimated by means of a two-step procedure using all observations, no matter the purchase decision. In the first step, known as the purchase decision, probit estimates, $\hat{\alpha}_{i}$, of $\alpha_{i}$ are obtained and then they are used in the second step to calculate $\varphi\left(Z_{\text {in }}{ }^{\prime} \hat{\alpha}_{i}\right) \& \Phi\left(Z_{\text {in }}{ }^{\prime} \hat{\alpha}_{i}\right)$ and estimate the parameters $\beta_{i} \& \delta_{i}$ in the system:

$$
\begin{aligned}
& y_{i n}=\Phi\left(Z_{i n}{ }^{\prime} \hat{\alpha}_{i}\right) f\left(X_{i n}, \beta_{i}\right)+\delta_{i} \varphi\left(Z_{i n}{ }^{\prime} \hat{\alpha}_{i}\right)+\eta_{\text {in }} \\
& (i=1, \ldots, M \& n=1, \ldots, N)
\end{aligned}
$$

where $\varphi\left(Z_{\text {in }}{ }^{\prime} \alpha_{i}\right)$ is the normal probability density function (pdf) evaluated at $Z_{\text {in }}{ }^{\prime} \alpha_{i}, \Phi\left(Z_{\text {in }}{ }^{\prime} \alpha_{i}\right)$ is the normal cumulative density function (cdf) evaluated at $Z_{\text {in }}{ }^{\prime} \alpha_{i}$ and $\eta_{i n}$ is the error term; 
The equation system represented in (3) is estimated by maximum likelihood with a non-linear Seemingly unrelated regression (SUR). To implement the Shonkwiler and Yen estimation procedure, it is necessary to specify the demands' functional form $f\left(X_{i n}, \beta_{i}\right)$. The Quadratic Almost Ideal Demand System (QUAIDS) is employed, below. The QUAIDS model has more flexibility than the well known Almost Ideal Demand System (AIDS), allowing for non-linear Engel curves but maintaining all the relevant properties of its linear counterpart. ${ }^{7}$ It relates the expenditure share of each good to the usual explanatory variables (price and income), and to variables that capture consumers' heterogeneity. Substituting the QUAIDS functional form into equation (3), the system to be estimated becomes:

$$
\begin{aligned}
& w_{i n}=\Phi\left(Z_{i n}{ }^{\prime} \hat{\alpha}_{i}\right)\left(\sum_{k=1}^{n} \theta_{i k} V_{k}+\sum_{j=1}^{n} \gamma_{i j} \ln p_{j}+\beta_{i} \ln \left[\frac{m}{a(p)}\right]+\frac{\lambda_{i}}{b(p)}\left\{\ln \left[\frac{m}{a(p)}\right]\right\}^{2}\right)+\delta_{i} \phi\left(Z_{i n}{ }^{\prime} \hat{\alpha}_{i}\right)+\eta_{i n} \\
& (i=1, \ldots, M \& n=1, \ldots, N)
\end{aligned}
$$

where

$w_{i n}=\frac{p_{\text {in }} q_{\text {in }}}{m}=$ ith food product expenditure share for consumer $\mathrm{n}$;

$V_{k}=$ Demographic variables;

$p_{j}=$ Price of good i;

$q_{i}=$ Quantity of good i;

$m=$ Monthly household income

$\ln a(p)=\sum_{j=1}^{n} w_{j}^{0} \ln p_{j}$.

$w_{j}^{0}=$ mean shares.

$b(p)=\prod_{k} p_{k}^{\beta_{\lambda}}$.

$\theta_{i}, \beta_{i}, \delta_{i}, \gamma_{i j}, \lambda_{i}=$ Parameters.

With Shonkwiler and Yen estimation ensuring adding up is a problem. The usual parameters restriction method only guarantees adding up of the latent expenditure shares, but not observed expenditure shares (DONG; GOULD; KAISER, 2004). One solution to this problem ${ }^{8}$ is to treat one of the products as a "residual good" and to estimate the system with (n-1) goods. Then, we have the nth equation as:

7 See Banks, Blundell and Lewbel (1997)

8 See Yen and Huang (2002). 


$$
w_{n}=1-\sum_{k=1}^{n-1}\left[f_{k}\left(X_{i n}, \beta_{n}\right)+e_{k}\right]=f_{n}\left(X_{i n}, \beta_{n}\right)+e_{n}
$$

where

$f\left(X_{i n}, \beta_{i}\right)=$ Functional form of the demand function;

$f_{n}\left(X_{i n}, \beta_{i}\right)=1-\sum_{k=1}^{n-1}\left[f_{k}\left(X_{i n}, \beta_{n}\right)\right]$;

$e_{n}=-\sum_{k=1}^{n-1} e_{k}$

This method guarantees that the sum of the (n-1) estimated equations and the nth equation equals one. Then, the likelihood function is constructed only with the first (n-1) equations. The elasticities of the nth good can be calculated by the adding up restrictions.

There are some problems with this method. First, parameter estimates are not invariant to the commodity chosen for omission. Second, there is no guarantee that estimated expenditure shares will be non-negative. Nevertheless, this solution is used here as it was felt that problems caused by zero consumption were the most severe. The residual commodity generally chosen is the good that the researcher has the least interest. ${ }^{9}$ Sugar is excluded during estimation because its share of consumers' expenditure is small.

\section{Results}

\subsection{First Step Results}

Shonkwiler and Yen first step estimation consists of estimating equations using the probit model for each food product. The dependent variable is a dichotomous variable which is 1 if the consumer purchases the product and zero otherwise. The explanatory variables we used are presented in Table 1 :

9 Generally, the residual commodity is the category 'other foods', very common in demand studies. See ibidem. 


\section{Explanatory Variables:}

- Constant (called ONE)

- Natural Logarithm of the monthly household income (called INCOME);

- Regional Dummies:

$>$ NORTH;

$>$ NORTHEAST;

$>$ SOUTH;

$>$ SOUTHEAST (will be the default);

$>$ CENTER-WEST (called CENTER-W);

- Household location Dummy (called URBAN):

$>\quad$ Urban $=1$;

$>$ Rural $=0$.

- Household Head Education Dummies:

$>\quad$ No education (called NO-ED)

$>$ Incomplete Elementary and junior high (called INCO-ELE);

$>$ Complete Elementary and junior high (will be the default);

$>$ Incomplete high school(called INCO-HI);

$>$ Complete high school (called COMP-HI);

$>$ Incomplete College education (called INCO-COL);

$>$ Complete College education (called COMP-COL);

- Household Head Race Dummies:

$>$ BLACK;

$>$ WHITE (will be the default);

$>$ ASIAN;

$>$ MIXED;

$>$ OTHER;

- Household Head Gender Dummy (called WOMAN):

$>$ Woman $=1$;

$>\quad M a n=0$

- Household Maid Dummy (called DOMESTIC):

$>$ Has a maid $=1$;

$>$ Does not have a maid $=0$;

- Household Refrigerator dummy (called REFRIG):

$>$ Owns a refrigerator $=1$;

$>$ Does not own a refrigerator $=0$;

Table 1 - Explanatory Variables Used in The Demand System Estimation First Step 
First step results are presented in table Al in the appendix. ${ }^{10}$ A general inspection reveals that 263 out of 360 coefficients are significant (73.06\%). Coefficient signs mostly correspond to expectations. For income, for example, an increase in household income causes a decrease in the purchase probability of rice and sugar. For beans and manioc flour, income coefficients are also negative, but not statistically significant. For other products, an increase in household income causes an increase of the purchase probability.

For regional differences, most coefficients are significant, showing that there are specific regional differences in consumption in relation to the southeast region (default), even though we control for income differences. This is an important result because it suggests that the purchase probabilities for some food products are influenced by regional factors (taste, existence of substitutes, etc.) and not only by the very sharp regional differences in income that exist in Brazil. For example, purchase probabilities for pork are much higher in the south than in the other regions of the country. Accordingly, North and Northeast ${ }^{11}$ variables have a positive impact on purchase probabilities for some basic food products such as rice, beans and manioc flour. Some results were surprising, such as the positive coefficient for the Northeast in the high quality beef equation, since the consumption of this product is much higher in the southeast region. One possible explanation is that, controlling for differences in income, household consumption is higher in the northeast area whereas high quality beef consumption away from home is higher in the southeast.

Only two of eighteen INCO-HI coefficients and eight of eighteen COMP-HI are significant. Thus, there is almost no difference in purchase probability between households whose head has a high school education (complete or not) and households whose head completed only junior high or less. Nevertheless, coefficients of other educational variables, such as NO-ED, INCO-COL, and COMP-COL are significant, for the most part, and the signs are almost all negative. When the household head has no education, positive coefficients result for sugar, rice, manioc flour, beans and low grade beef (not significant) and negative values for other products. Demand for cheaper, high-energy foods, such as rice, sugar and manioc flour is higher for those who have to do manual labor, which is very common for those who have little or no education. Results for the college degree variables show negative coefficients for all products with exception of cheese and butter (not significant), indicating smaller purchase probabilities than households whose head have

10 The software used was GAUSS 6.0 for Windows, Copyright 1984-2003, Aptech Systems, Inc.

11 North and Northeast regions are the poorest regions in Brazil, with health statistics comparable to poor African nations. 
completed only junior high. This result may stem from more educated households eating out more often than their less educated counterparts.

Results for urban-rural coefficients are significant for all products except chicken, pasta and pork. The signs are according to expectation, with negative values for cheaper, high-energy foods indicating a higher purchase probability in rural areas and positive signs for products such as French rolls, beef, cheese, powdered milk, meaning that their purchase probability is higher in urban areas.

Results for race variables show that 30 out of 72 coefficients are not significant, especially the coefficients from ASIAN and OTHERS variables. Thus, for most commodities, there is no significant difference between those households whose head is Asian or from other race (except black, white, or mixed) and households whose head are white. The results for BLACK and MIXED show a positive influence in the purchase probability of sugar, rice, low quality beef, manioc flour and negative influence on fluid milk, high quality beef, bananas, potatoes, tomatoes, and cheese.

Results for influence of household head gender show that most coefficients are significant and negative; for example, for sugar, rice and beans. For milk, the coefficient is not significant and for cheese there is a significant and positive coefficient. For bananas and French rolls, this variable has a positive influence on the purchase probability. It is hard to find a complete explanation for this behavior. The expectation was that women have greater concern with health issues than men and that WOMAN should have a positive effect on healthy foods (fruits, vegetables, etc.) and a negative impact on less healthy foods (meats, cheese, etc.). Gender had a significant positive effect on only the purchase probability of bananas, French rolls, and cheese. Households with women heads have smaller purchase probabilities in most of the other commodities in the sample.

The other two variables (DOMESTIC and REFRIG) intend to capture the effect of the presence of a maid and of a refrigerator in the household, ${ }^{12}$ respectively. Results for DOMESTIC differed somewhat from expectation. The presence of a maid decreases the purchase probability for some foods such as beans and lower quality meats. For rice, the coefficient is not significant. For tomatoes, potatoes, milk, cheese, and high quality beef the estimated coefficients were significantly positive. This is probably the result of two effects. First, maids are preparing meals using

12 In Brazil, the presence of maids working in households is not uncommon and they are usually responsible for meals (shopping, preparing, etc...). In the estimation sample, 9.34\% of the households have maids. For refrigerators, very poor families in Brazil usually don't have electricity (and logically refrigerators, which are absent in nearly $20 \%$ of the households sampled), so it's difficult to conserve foods for a long period of time, affecting food purchase patterns. 
higher quality, more expensive ingredients. Second, many of the households which have maids consume more meals away from home.

Results for REFRIG were in keeping with expectations, especially for milk. The presence of refrigerator in the household increases the purchase probabilities for fluid milk and decreases for powdered milk. This result helps to explain why poorer families in Brazil consume a relatively more expensive product (powdered milk) in the presence of a cheaper substitute (fluid milk). ${ }^{13}$ The presence of a refrigerator also has a positive influence in purchase probabilities of meat, with exception of pork, whose coefficient is not significant. A positive effect is also observed for cheese. A negative effect is observed for staple foods, such as rice, beans, manioc flour and sugar. What is happening here is, controlling for other effects, a substitution of staple foods to more expensive products that were cited above which demand refrigeration.

\subsection{Second Step Results}

Second step estimation variables are in Table $2 .{ }^{14}$ Some variables that were used in the first step are also used in the second, such as monthly household income, education dummies, household location dummy and the refrigerator dummy. The repetition of the first two variables occurs because they are important not only to the purchase decision, but also in the quantity decision. The repetition of the last two variables is justified by the need of a more complete understanding on how these variables impact food demand in Brazil. The second step estimation also includes household composition variables, commonly used in demand studies. ${ }^{15}$

13 See descriptive statistics for the variables in table A2 in the appendix.

14 All variables except the last are multiplied by the cumulative normal evaluated at the first stage estimates. See equation (4).

15 See, for example, Thomas et al. (op. cit.) and Yen, Kan and Su (op. cit.). 


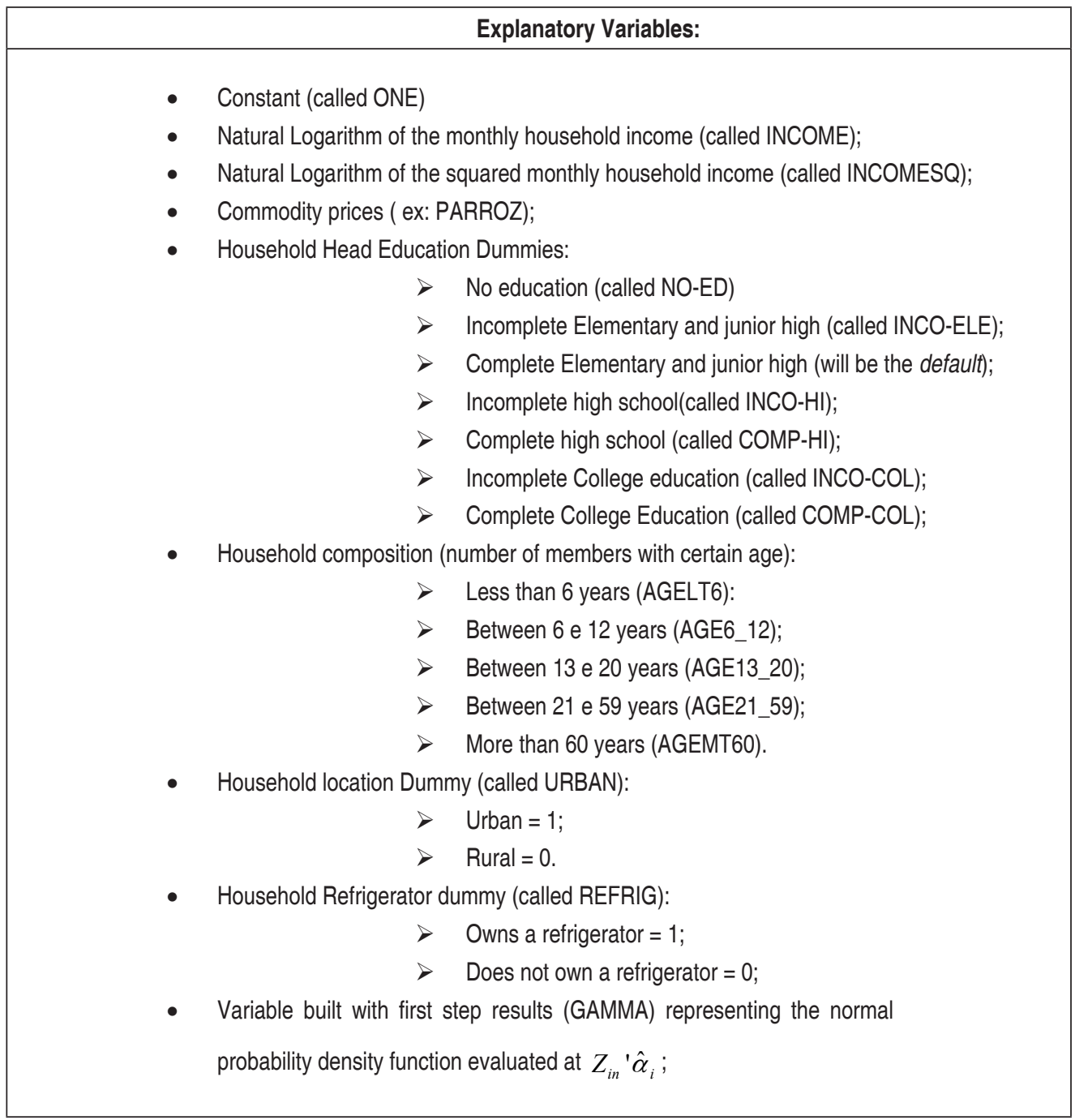

Table 2 - Explanatory Variables Used in the Demand System Estimation Second Step

Elasticities are calculated from the results according to the formulas given in Banks, Blundell, and Lewbel (op. cit.) (at the sample mean shares). Income elasticity estimations are presented in Table 3. Surprisingly, there are no inferior goods in the sample. Moreover, only 6 out of 18 elasticities are bigger than one, indicating a predominance of normal goods. Among the luxuries, sugar, bananas and high quality beef have the biggest elasticities. Among the meat products, pork and chicken have elasticities close to one, while the low quality beef elasticity is slightly smaller. 
Table 3 - Demand Income Elasticities, Brazil, 2002 - 2003

\begin{tabular}{lc}
\hline PRODUCTS & ELASTICITY \\
\hline Sugar & 1.8987 \\
Rice & 0.8384 \\
Bananas & 1.1352 \\
Potatoes & 1.0427 \\
High quality beef & 1.1336 \\
Low quality beef & 0.8375 \\
Manioc Flour & 0.8573 \\
Beans & 0.8455 \\
Chicken & 0.9959 \\
Powdered Milk & 1.0763 \\
Fluid Milk & 0.8349 \\
Pasta & 0.9645 \\
Butter & 0.9678 \\
Margarine & 0.9752 \\
French Rolls & 0.9443 \\
Pork & 0.9988 \\
Cheese & 1.1297 \\
Tomatoes & 0.9586 \\
\hline Source: Estimation result &
\end{tabular}

Source: Estimation results.

The elasticities of staple foods (rice, beans and manioc flour) were bigger than expected, since the initial expectations were that the elasticities were in the $[0.1$, $0.4]$ range, even with possibility of negative values. Another surprise was the elasticities of fluid and powdered milk. Previous studies (HOFFMANN, 2000, 2007; MENEZES et al., 2002) found bigger elasticities for fluid milk and negative elasticities for powdered milk, indicating that the latter is an inferior good. Our results show that powdered milk (the most expensive product) is a luxury and fluid milk (the cheapest) is a normal good. This is probably due to the inclusion of the rural territories in Brazil which had been excluded from previous surveys.

In general, income elasticities were larger than most previous studies (SILVEIRA et al, 2007a; HOFFMANN, 2007), but similar to the expenditure elasticities from Alves, Menezes and Bezerra (2007). The differences might be caused by: a) different level of aggregation. Previous studies generally used aggregation over consumers by income levels. This could trigger differences in elasticities' estimates 
(BLUNDEL; PASHARDES; WEBER, op. cit.). Studies with similar methodology and consumer aggregation to this paper, e.g. Berges e Casellas (2007) for Argentina, find expenditure elasticities ${ }^{16}$ ranging from 0,68 to 2,01 , with the majority close to 1 as was the case of this study; b) inclusion of education dummies in both stages. As education was negatively related to the consumption of most food products (even controlling by income effects), especially for staple foods, and as education is generally positive correlated to income, previous studies that did not account for education should be expected to have smaller income elasticities estimates. Additional studies using the same methodology are needed to confirm these claims.

Results for Marshalian (uncompensated) price elasticities are reported in Table 4. Own-price elasticities are negative for all commodities, with the exception of butter. This suggests some problem in estimation perhaps caused by low frequency of consumption of butter in the sample (a little more than $5 \%$ ), but such a result is not unusual in large demand systems, e.g. Huang (1999).

Other surprising results are the high values of own-price elasticities for staples: rice, beans and manioc flour are price elastic with values as high as -1.98 for manioc flour. Meat products, by comparison, have smaller elasticities, ranging from -1.67 (pork) to -0.98 (high quality beef). For other commodities, the majority of demands are elastic, with the exceptions of tomatoes (-0.60), margarine (-0.94) and powdered milk (-0.81). Although not directly comparable with Berges e Casellas (op. cit.) estimates, since they used more aggregated products, own-price elasticities are usually higher here. On the other hand, estimates from Alves, Menezes and Bezerra (op. cit.) were consistently higher, probably due to the bigger time of adjustment captured by using a pseudopanel.

Results for cross price elasticities show that rice substitutes for pasta, French rolls, potatoes and manioc flour, all alternative carbohydrate sources. Rice is also a complement to beans, beef and tomatoes. Beans are substitutes for manioc flour, an unexpected result since their joint consumption is a strong habit in the northeast region. Beans are complements to meat and dairy products (with exception of powdered milk), all alternative sources of protein.

For meats, Table 4 reports that high quality beef is a substitute for chicken and pork. The odd result is the complementary relation between the two types of beef, which are usually regarded as substitutes. Results for milk show the expected substitutability between powdered and fluid milk: a $10 \%$ increase in the price of powdered milk causes a $5.58 \%$ increase in fluid milk consumption.

16 Income elasticities were also calculated, however as they were calculated by an auxiliary regression, expenditure elasticities were the equivalent of this paper income elasticities. 







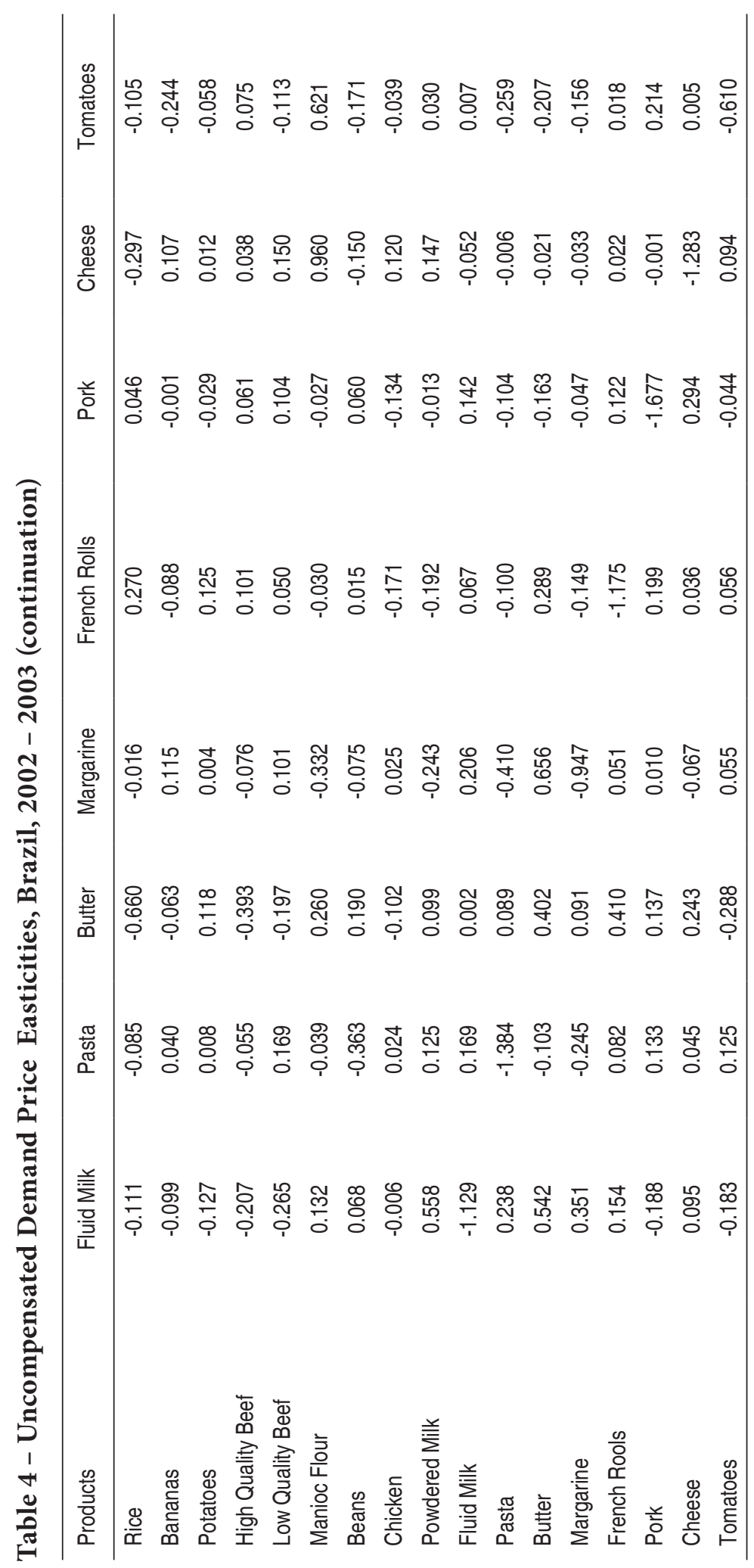




\section{Conclusions}

Several interesting features of Brazilian demand for food products have been presented. In general, the larger is a family's income, the smaller is the probability of purchasing staple foods and the larger is the probability of purchasing meat, milk and other products as would be expected.

Regional variables were also important in the demand system. They were important not only for the so called "regional foods", such as manioc flour in the North and Northeast or beef in the South, but also for almost all the commodities.

Women's role as household heads is also important in understanding differences in food consumption. Results show that there is a smaller purchase probability for almost all goods in our sample when women are household heads. The reason is straightforward: when women work, meals away from home are substituted for at home meals.

Second stage results were more problematic than the first stage ones. Estimated income elasticities showed all goods were normal. Sugar, High quality beef, bananas, cheese and powdered milk were found to be luxuries. Some staples were more price elastic than expected. Cross price elasticities results agreed with expectations, for the most part.

This paper main contribution was to account for the zero expenditure problem usually overlooked in similar studies but always present when we deal with a large household consumption data. Results showed that elasticities were generally higher when we consider this issue. A limitation of our analysis is the low number of fruits and vegetables in the sample, not allowing a more careful analysis about the role of health concerns in food consumption patterns. Another issue which we do not deal with is the infrequency of purchase problem, i.e., the observed zero consumption by a household may be a result of infrequency of purchases and not a corner solution. Further research is needed to incorporate these issues in the Brazilian food demand system estimation.

\section{References}

AGUERO, J. M.; GOULD, B. W. Household composition and Brazilian food purchases: an expenditure system approach. Canadian Journal of Agriculture Economics, v. 51, n. 3, p. 323-345, 2003.

ALVES, D., MENEZES T.; BEZERRA, F. Estimação do sistema de demanda censurada para o Brasil: utilizando dados de pseudopainel. In: SILVEIRA, F. G.; SERVO, 
L. M. S.; MENEZES, T.; PIOLA, S. F. (Org.). Gasto e consumo das famílias brasileiras contemporâneas. Brasília: IPEA, p. 395-422, 2007. v. 2.

BACCHI, M.R.P. Demanda de carne bovina no mercado brasileiro. 1989. Piracicaba, ESALQ/USP, 77p. (unpublished Master dissertation).

BANKS, J.; BLUNDELL, R.; LEWBEL, A. Quadratic Engel curves and consumer demand. The Review of Economics and Statistics, v. LXXIX, n. 4, p.527-539, Nov. 1997.

BATALHA, M.O.; LUCCHESE, T.; LAMBERT, J.L. Hábitos de consumo alimentar no Brasil: realidade e perspectivas. In: BATALHA, Mario O. (Coord.). Gestão do Agronegócio - Textos selecionados. São Carlos: Edufscar, 2005.

BERGES, M; CASELLAS, K. Estimación de um sistema de demanda de alimentos: um análisis aplicado a hogares pobres y no pobres. In: SILVEIRA, F. G.; SERVO, L. M. S.; MENEZES, T.; PIOLA, S. F. (Org.). Gasto e consumo das famílias brasileiras contemporâneas. Brasília: IPEA, p.529-551, 2007. v. 2.

BLUNDELL, R.; PASHARDES, P.; WEBER, G. What do we learn about consumer demand patterns from microdata. American Economic Review, 83 (3), p.570597, June 1993.

DONG, D.; GOULD, B.W.; KAISER, H.M. Food demand in Mexico: an application of the Amemiya-Tobin approach to the estimation of a censored food system. American Journal of Agriculture Economics, v. 86, n. 4, p. 1094-1107, 2004.

FURTUOSO, M. C. O. Redistribuição de e consumo de Alimentos no Estado de São Paulo. 1981. Piracicaba, ESALQ/USP, 106p. (unpublished Master dissertation).

GREENE, W.H. Econometric analysis. Prentice Hall, Upper Saddle River, Fourth edition, 2000, 1004p.

HAINES, P. S.; GUILKEY, D. K.; POPKIN, B.M. Modeling food consumption decisions as a two-step process. American Journal of Agricultural Economics, v. 70, n. 3, p. 543-552, Aug. 1988.

HEIEN, D.; WESSELS, C.R. Demand systems estimation with microdata: a censored regression approach. Journal of Business and Economic Statistics, v. 8, n. 3, July 1990.

HOFFMANN, R. A diminuição do consumo de feijão no Brasil. Estudos Econômicos, v. 25, n. 2, p. 189-201, maio-ago. 1995.

. Elasticidades-renda das despesas e do consumo físico de alimentos no Brasil metropolitano em 1995-96. Agricultura em São Paulo, SP, v. 47, n. 1 p. 111 $122,2000$.

. Elasticidades-renda das despesas e do consumo de alimentos no Brasil em 2002-2003. In: SILVEIRA, F. G.; SERVO, L. M. S.; MENEZES, T.; PIOLA, S. F. (Org.). Gasto e consumo das famílias brasileiras contemporâneas. Brasília: IPEA, p. 463-485, 2007. v. 2. 
HUANG, K. Effects of food prices and consumer income on nutrient availability. Applied Economics, 31, p. 367-380, 1999.

IBGE. Pesquisa de Orçamentos Familiares 2002-2003. Aquisição alimentar domiciliar per capita: Brasil e grandes regiões. Rio de Janeiro: Instituto Brasileiro de Geografia e Estatística, 2004a.

Pesquisa de Orçamentos Familiares 2002-2003. CD-ROM -Microdados - Segunda divulgação. Rio de Janeiro: Instituto Brasileiro de Geografia e Estatística, 2004b.

LEE, L. F; PITT, M. M. Microeconometric demand systems with binding nonnegativity constraints: the dual approach. Econometrica, v. 54, n. 5, p. 1237-1242, Sep. 1986.

MANCHESTER, A. C. Household consumption behavior: understanding, measurement, and applications in policy-oriented research. American Journal of Agricultural Economics, v. 59, n. 1, p. 149-154, Feb. 1977.

MENEZES, T.; SILVEIRA, F. G; AZZONI, C.R. Demand elasticities for food products: a two-stage budgeting system. NEREUS-USP, São Paulo, 2005 (TD Nereus 09-2005).

MENEZES, T.; SILVEIRA, F. G; MAGALHÃES, L.C.G.; TOMICH, F.A.;VIANNA, S.W. Gastos alimentares nas grandes regiões urbanas do Brasil: aplicação do modelo AID aos microdados da POF 1995/1996 IBGE. Brasília: IPEA, 2002 (Discussion Paper, n. 896).

MURPHY, K. M.; TOPEL, R. H. Estimation and inference in two-step econometric models. Journal of Business and Economic Statistics 3, p. 370-379, Oct. 1985.

SHONKWILER, J. S.; YEN, S.T. Two-step estimation of a censored system of equations. American Journal of Agricultural Economics. v. 81, n. 4, p. 972-982, Nov. 1999.

SILVEIRA, F. G.; MENEZES, T.; MAGALHÃES, L.C.G.; DINIZ, B. P. C. Elasticidade-renda dos produtos alimentares nas regiões metropolitanas brasileiras: uma aplicação da POF 1995/1996. Estudos Econômicos, v. 37, n. 2, p. 329-352, 2007a.

SILVEIRA, F. G.; SERVO, L. M. S.; MENEZES, T.; PIOLA, S. F. Gasto e consumo das famílias brasileiras contemporâneas. Brasília: IPEA, 2007b, 551 p. v. 2.

THOMAS, D.; STRAUSS, J.; BARBOSA, M. M. T. Estimativas do impacto de mudanças de renda e de preços no consumo no Brasil. Pesquisa e Planejamento Econômico, v. 21, n. 2, p. 305-354, 1991.

WALES, T. J.; WOODLAND, A. D. Sample selectivity and the estimation of labor supply functions. International Economic Review, v. 21, n. 2, p. 437-468, June 1980. 
YEN, S. T; HUANG, C. L. Cross-sectional estimation of U. S. demand for beef products: a censored system approach. Journal of Agricultural and Resource Economics, v. 27, n. 2, p. 320-334, 2002.

YEN, S.T.; KAN, K.; SU, S. Household demand of fats and oil: two-step estimation of a censored demand system. Applied Economics, v. 34, n. 14, p. 1799-1806, 2002. 


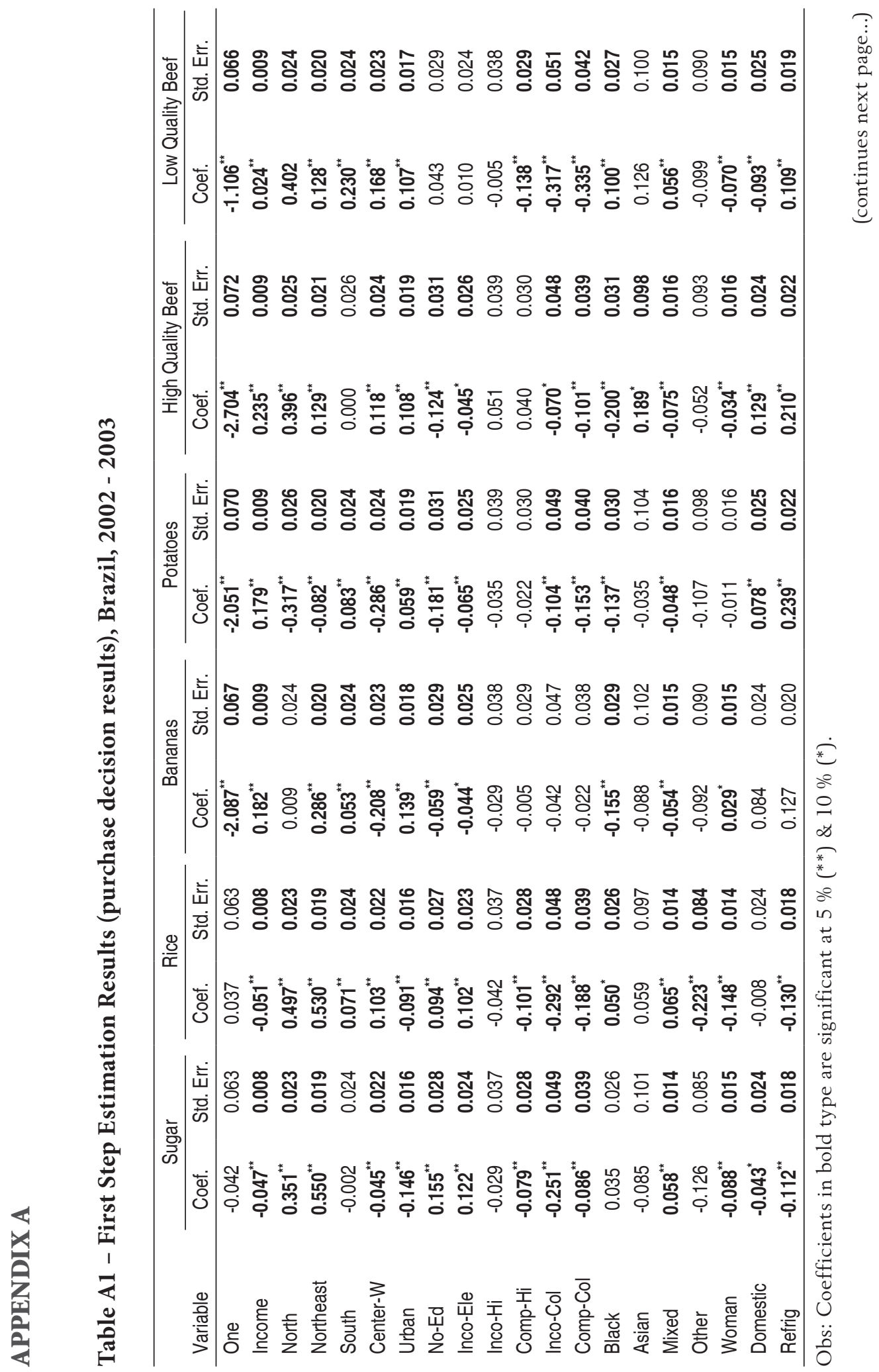




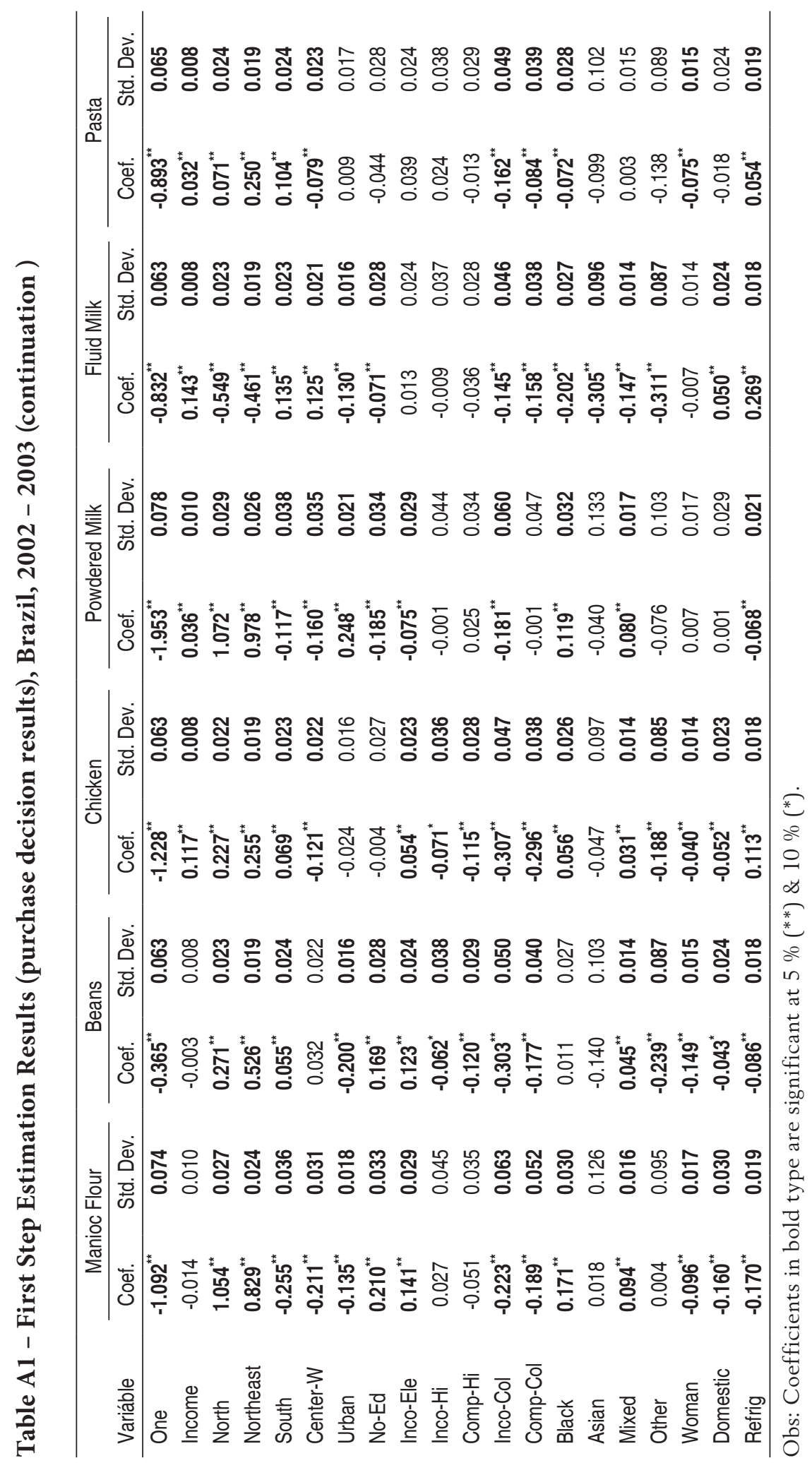




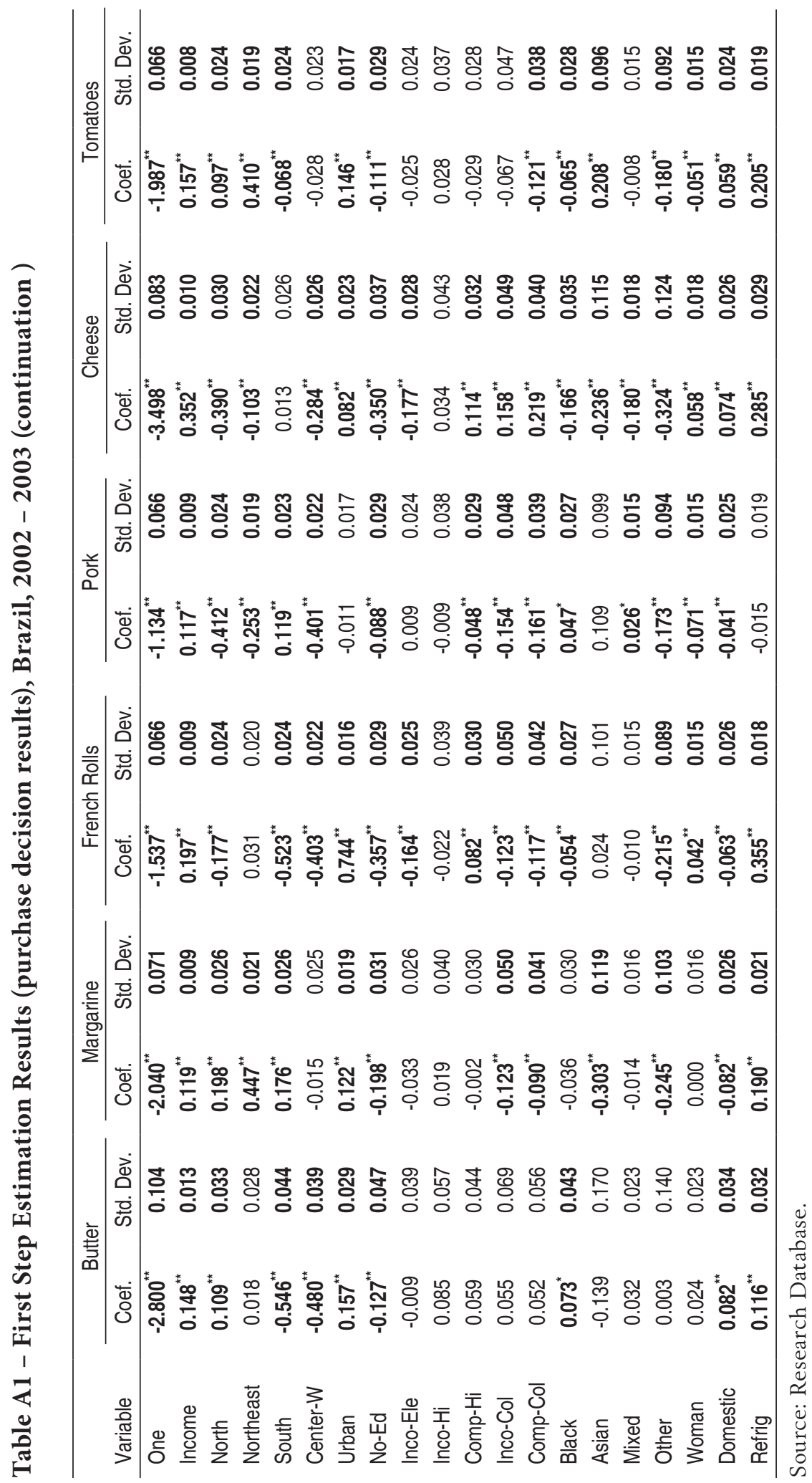


Table A2 - Descriptive Statistics of Variables

\begin{tabular}{|c|c|c|}
\hline Explanatory Variables: & Stage & Mean \\
\hline Monthly household income ${ }^{1}$ (R\$) & 1,2 & 1525.63 \\
\hline \multicolumn{3}{|l|}{ Regional Dummies: } \\
\hline North; & 1 & 0.144 \\
\hline Northeast; & 1 & 0.394 \\
\hline South; & 1 & 0.125 \\
\hline Southeast & 1 & 0.177 \\
\hline Center-West (called Center-W); & 1 & 0.160 \\
\hline \multicolumn{3}{|l|}{ Household location Dummy (called Urban): } \\
\hline Urban = 1 & 1,2 & 0.781 \\
\hline Rural $=0$ & 1,2 & 0.219 \\
\hline \multicolumn{3}{|l|}{ Household Head Education Dummies: } \\
\hline No education (called No-Ed) & 1,2 & 0.171 \\
\hline Incomplete Elementary and junior high (called Inco-Ele); & 1,2 & 0.071 \\
\hline Complete Elementary and junior high (will be the default); & 1,2 & 0.513 \\
\hline Incomplete high school(called Inco-Hi); & 1,2 & 0.043 \\
\hline Complete high school (called Comp-Hi); & 1,2 & 0.130 \\
\hline Incomplete College education (called Inco-Col); & 1,2 & 0.023 \\
\hline Complete College education (called Comp-Col); & 1,2 & 0.049 \\
\hline \multicolumn{3}{|l|}{ Household Head Race Dummies: } \\
\hline Black; & 1 & 0.065 \\
\hline White (will be the default); & 1 & 0.435 \\
\hline Asian; & 1 & 0.004 \\
\hline Mixed; & 1 & 0.490 \\
\hline Other; & 1 & 0.005 \\
\hline \multicolumn{3}{|l|}{ Household Head Gender Dummy (called Woman): } \\
\hline Woman = 1 & 1 & 0.258 \\
\hline Man = 0 & 1 & 0.742 \\
\hline \multicolumn{3}{|l|}{ Household Maid Dummy (called Domestic): } \\
\hline Has a maid = 1 ; & 1 & 0.093 \\
\hline Does not have a maid = 0 & 1 & 0.907 \\
\hline \multicolumn{3}{|l|}{ Household Refrigerator dummy (called Refrig): } \\
\hline Owns a refrigerator $=1$ & 1,2 & 0.810 \\
\hline Does not own a refrigerator $=0$ & 1,2 & 0.190 \\
\hline \multicolumn{3}{|l|}{ Commodity prices $^{1}(\mathrm{R} \$ \mathrm{~kg})$ ); } \\
\hline Rice & 2 & 1.57 \\
\hline Bananas & 2 & 1.21 \\
\hline Potatoes & 2 & 1.28 \\
\hline High quality beef & 2 & 6.19 \\
\hline Low quality beef & 2 & 4.26 \\
\hline Manioc Flour & 2 & 1.34 \\
\hline Beans & 2 & 2.23 \\
\hline Chicken & 2 & 3.37 \\
\hline Powdered Milk & 2 & 9.88 \\
\hline Fluid Milk & 2 & 0.99 \\
\hline Pasta & 2 & 3.85 \\
\hline Butter & 2 & 7.10 \\
\hline Margarine & 2 & 4.99 \\
\hline French Rools & 2 & 3.68 \\
\hline Pork & 2 & 4.64 \\
\hline Cheese & 2 & 8.92 \\
\hline Tomatoes & 2 & 1.09 \\
\hline \multicolumn{3}{|c|}{ Household composition (number of members with certain age): } \\
\hline Less than 6 years (AGELT6): & 2 & 0.519 \\
\hline Between 6 e 12 years (AGE6_12); & 2 & 0.482 \\
\hline Between 13 e 20 years (AGE13_20); & 2 & 0.662 \\
\hline Between 21 e 59 years (AGE21_59); & 2 & 1.862 \\
\hline More than 60 years (AGEMT60). & 2 & 0.318 \\
\hline
\end{tabular}

Obs: 1 . R $\$ 1=$ US\$ 0.3039 in $01 / 15 / 2003$. 
Table A3 - Total Expenditure Average Share of the Eighteen Food Products, Brazil, 2002-2003

\begin{tabular}{lc}
\hline PRODUCTS & SHARE $(\%)$ \\
\hline Sugar & 5.91 \\
Rice & 10.33 \\
Bananas & 2.66 \\
Potatoes & 1.62 \\
High quality beef & 7.02 \\
Low quality beef & 7.41 \\
Manioc Flour & 2.91 \\
Beans & 6.26 \\
Chicken & 11.01 \\
Powdered Milk & 3.28 \\
Fluid Milk & 11.25 \\
Pasta & 2.98 \\
Butter & 0.49 \\
Margarine & 1.72 \\
French Rolls & 15.46 \\
Pork & 5.44 \\
Cheese & 2.56 \\
Tomatoes & 1.69 \\
\hline Source: Resear &
\end{tabular}

Source: Research Database. 


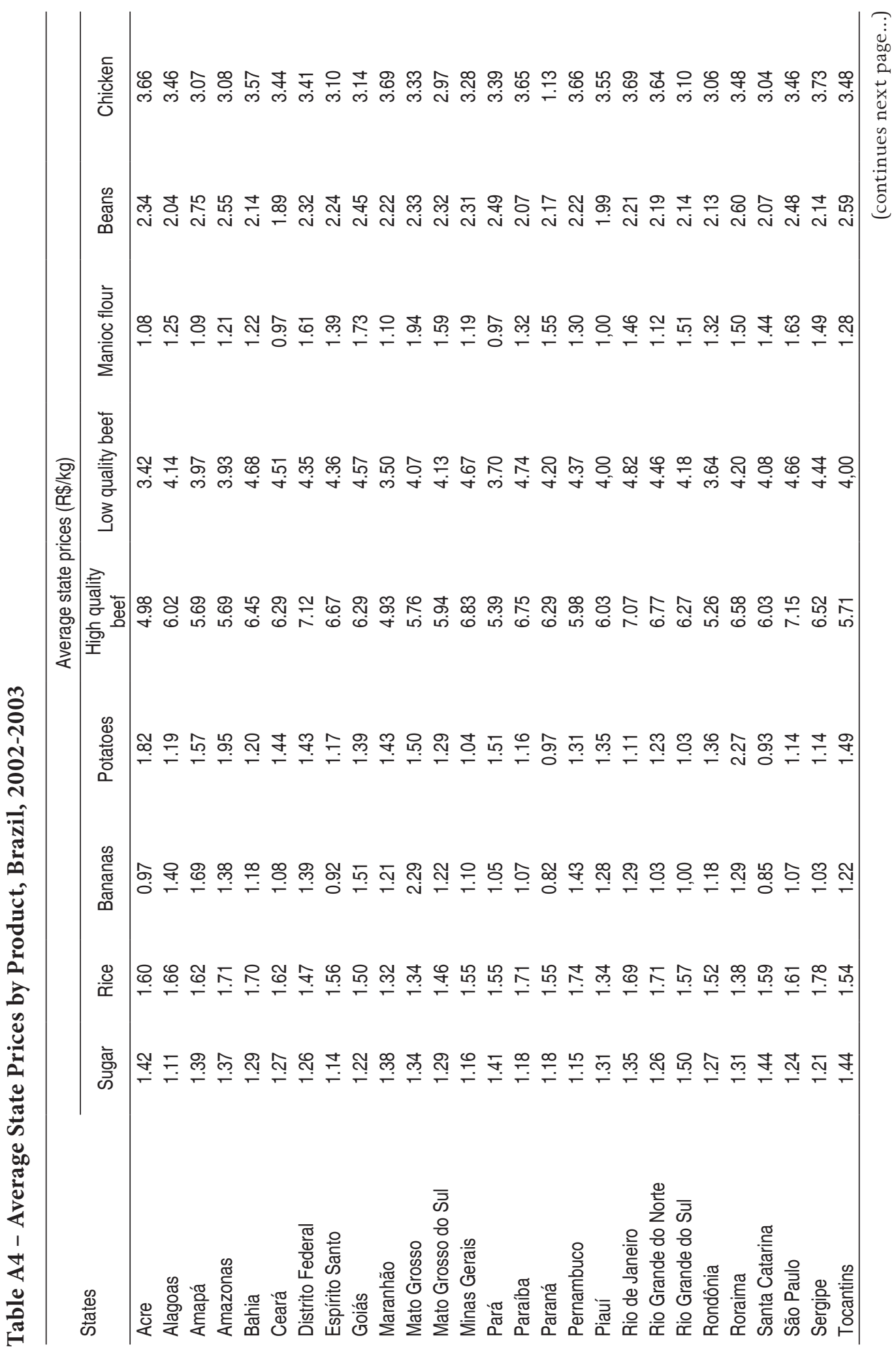




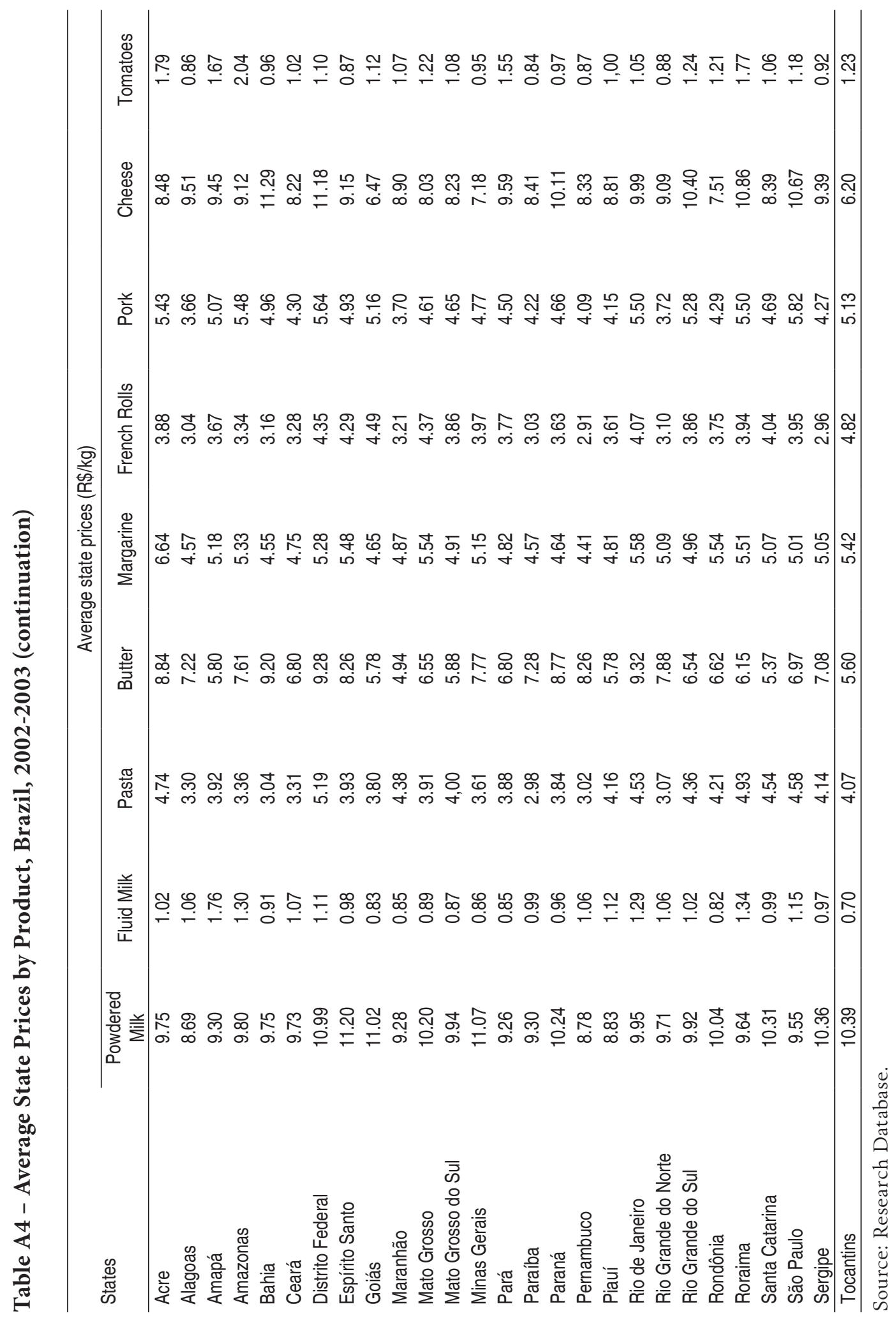

